\title{
Appraisal of Cocoa swollen shoot virus (CSSV) Mild Isolates for Cross Protection of Cocoa Against Severe Strains in Ghana
}

\author{
G. A. Ameyaw, O. Domfeh, H. Dzahini-Obiatey, L. A. A. Ollennu, and G. K. Owusu, Cocoa Research Institute of Ghana, New Akim-Tafo, \\ E/R, Ghana
}

\begin{abstract}
Ameyaw, G. A., Domfeh, O., Dzahini-Obiatey, H., Ollennu, L. A. A., and Owusu, G. K. 2016. Appraisal of Cocoa swollen shoot virus (CSSV) mild isolates for cross protection of cocoa against severe strains in Ghana. Plant Dis. 100:810-815.

Two mild strains of Cocoa swollen shoot virus (CSSV), N1 and SS365B, were assessed for their capability to mitigate the devastating effects of CSSV in field trials at the Cocoa Research Institute of Ghana in comparison with noninoculated cocoa plants. Analysis of growth, mortality, and yield of cocoa trees inoculated with the mild strains over a period of two decades between 1996 and 2014 indicated that the cocoa plants inoculated with mild strains performed significantly $(P<0.05)$ better in the presence of the severe strains (CSSV 1A) than noninoculated cocoa, albeit degenerated over time. The development of cocoa hybrids studied in

the trial showed differences in their performance in the presence of the mild-strain viruses. Spread of the severe virus increased and deteriorated the effects of the mild isolates over time, thereby decreasing the economic life span of the cocoa trees. This observation was consistent in all the trials regardless of the type of mild strain involved. Apparently, the immunity and protection conferred by mild strains of CSSV (SS365B and N1) on cocoa declined over time, and we further confirmed 'Amelonado' cocoa to be very susceptible to CSSV infection in terms of effects on growth and yield.
\end{abstract}

Cocoa swollen shoot virus disease (CSSVD) continues to be a serious challenge to cocoa production in West Africa, where the bulk (about 70\%) of the world's cocoa is produced (Ameyaw et al. 2014; Dzahini-Obiatey et al. 2010). Even though this particular viral disease was first detected in the Eastern Region of Ghana in 1936 (Posnette 1940; Stevens 1936), it has spread and is now reported in all the cocoa-growing regions of Ghana and other cocoa-growing countries of West Africa, including Cote D'Ivoire, Nigeria, Togo, and Cameroon (Ameyaw et al. 2014; Domfeh et al. 2011). The disease exhibits variable symptoms which are mostly seen on the leaves, stem, root, and pods of cocoa trees at all stages of growth and development (Posnette 1940). The characteristic stem swelling after which the disease is named could develop at the shoot tips, nodes, and internodes together with root swellings (Posnette 1940). Leaf symptoms are in the form of red vein clearing, yellow vein clearing or banding, green vein banding of fern-like pattern, diffused flecking, and blotches or streaks on the leaf lamina or between the leaf veins (Posnette 1940, 1941). Other symptoms such as leaf defoliation and tree dieback resulting in smaller and distorted or rounder pods with smooth surfaces are sometimes seen on affected cocoa trees (Posnette 1941). In severe cases, death of cocoa trees could occur within 2 to 5 years of infection, with yield loss of between 50 to $70 \%$ when the deadly (severe) strains of the virus are involved in infections (Muller 2008).

CSSVD is caused by the Cacao swollen shoot virus (CSSV), and mealybug insects (Pseudococcidae, Homoptera) are the main vectors of the virus (Posnette and Strickland 1948; Posnette et al. 1950; Roivainen 1976). The virus is transmitted to healthy cocoa trees and gets spread to other farms through the feeding activity of the mealybug insects (Posnette and Strickland 1948; Roivainen 1976). The mealybugs acquire the virus through feeding on all parts of infected cocoa

Corresponding author: G. A. Ameyaw; E-mail: gaakumfi@yahoo.co.uk

This article (CRIG/05/2015/042/005) is published with the kind permission of the Executive Director of the Cocoa Research Institute of Ghana (CRIG).

Accepted for publication 16 November 2015.

http://dx.doi.org/10.1094/PDIS-09-15-0974-RE

(C) 2016 The American Phytopathological Society trees, including chuppons, leaves, flowers, cherelles, and pods. Transmission of the virus to the host occurs in a semipersistent manner. In Ghana, it is known that the most effective and efficient mealybug species to transmit the virus are Planococcoides njalensis (Laing), Planococcus citri (Rossi), and Ferrisia virgata (Okll) (Posnette and Strickland 1948; Roivainen 1976). Mealybugs are generally difficult to control with insecticides. This is because their bodies have a white, fluffy, waterproof (mealy) covering which prevents spray chemical solution from getting into their body tissues to directly cause their death (Hanna 1954; Hanna et al. 1955; Roivainen 1976). Several attempts to use biological control agents such as parasitoids and predators have been tried in the past but have achieved limited success in controlling the mealybug (Ackonnor 1997). This has largely been attributed to the known symbiotic relationship between the mealybugs and their attendant ants (Ackonnor 1997). The ants protect the mealybugs by building mud tents to cover and guard them and, in return, receive sweet exudates from the mealybugs (Ackonnor 1997).

Over the years, CSSVD has been managed in Ghana through removal of infected trees from farms in a national program called the "cocoa cutting out and replacement programme". The broad objective is to prevent spread to new and noninfected areas. Thus, infected trees are removed from farms and replanted with healthy cocoa varieties (hybrids) which are tolerant to the virus (Ameyaw et al. 2014; Domfeh et al. 2011; Thresh et al. 1988). This method of control aims to reduce the build-up of viral inoculum within outbreak areas to contain the disease to only severely affected areas, commonly called areas of mass infection (Ameyaw et al. 2014; Dzahini-Obiatey et al. 2010; Thresh et al. 1988). Nonetheless, the cutting-out method has been fraught with several challenges. Key among these challenges has been opposition from farmers and inadequate funding of the program (Ameyaw et al. 2014; Thresh et al. 1988). This sometimes led to intermittent stoppages of the program and, hence, continuous build-up of inoculum and spread of the disease to new areas (Ameyaw et al. 2014). Therefore, there is a need to reconsider all other possible control methods in an integrated manner that would be cost effective and acceptable to all stakeholders to effectively manage further spread of the disease to new farms (Ameyaw et al. 2014).

The prospects of CSSV mild strain cross protection to confer immunity to cocoa trees against the more severe strains of the virus have been well studied at the Cocoa Research Institute of Ghana (CRIG) 
(Crowdy and Posnette 1947; Hughes and Ollennu 1994; Ollennu and Owusu 1989; Owusu 1996; Posnette and Todd 1955). The earliest studies by Crowdy and Posnette (1947) and Posnette and Todd (1951, 1955) provided the preliminary evidence about the potential of the mild-strain technique to protect cocoa plants against the severe strains of the virus. Their study formed the basis upon which further research in the area of CSSV mild-strain cross-protection trials started at CRIG. Although Posnette and Todd $(1951,1955)$ demonstrated the potential of mild strains to minimize the effect of the severe strains, the phenomenon was considered premature to be incorporated into methods of control for the disease. This is because some reservations were expressed about the possibility of the mild strains mutating to become severe strains; also, the unknown longterm consequences of the mild strains in cocoa needed to be further ascertained (Hughes and Ollennu 1994; Ollennu and Owusu 1989; Thresh et al. 1988). This necessitated the initiation and establishment of several new mild-strain trials in the early 1980s and 1990s at CRIG to further explore the long-term potential of the available CSSV mild strains to protect cocoa trees against severe types of the virus on growth, yield, and cocoa tree mortality (survival) (Hughes and Ollennu 1994; Ollennu and Owusu 1989; Owusu 1996). Results from these trials are anticipated to provide more information about the mild strains to help address some of the reservations and concerns raised by earlier scientists regarding the use of the CSSV mild-strain technology to manage the spread of the disease (Crowdy and Posnette 1947; Hughes and Ollennu 1994; Posnette and Todd 1955). This article reports on analysis of cumulative data on growth, yield, and mortality of different cocoa varieties inoculated with some mild strains from 1996 to 2014 in field trials to assess the long-term protective capability of two mild strains (N1 and SS365B). The article further discusses the implication of the current results on the use of the mild-strain cross-protection technology for CSSVD management in Ghana.

\section{Materials and Methods}

Virus source. CSSV mild-strain isolates SS365B and N1 were used. Cultures were maintained in cocoa plants referred to as virus source plants. Mealybugs (vectors of the virus) were fed on the infected source plants as described by Ollennu et al. (1994) to acquire the virus and for onward transmission onto cocoa beans.

Field trials (CRIG plot A23). Field experiments to evaluate the protective potential of CSSV mild strains N1 and SS365B were established in 1996 at CRIG plot A23 (Owusu et al. 1996). The objective of the trial is to assess more critically the effect of CSSV mild strains N1 and SS365B on growth and yield of a representative sample of the Amazon hybrids being planted by farmers. 'Amelonado' was included for comparison. Beans of the Amazon cocoa progenies T85/799 $\times$ PA7/808, T85/799 $\times \mathrm{T} 65 / 362, \mathrm{~T} 85 / 799 \times$ T79/501, T85/799 $\times$ Amelonado, T79/467 × T87/1312, and Amelonado were inoculated with either CSSV mild strain N1 or SS365B, using mealybugs, and planted in the gauzehouse to produce infected seedlings. Healthy (noninoculated) seedlings raised in the nursery served as control. Spacing was 2.5 by $2.5 \mathrm{~m}$ and tree population was 20 per plot arranged in a randomized complete block design. There were five treatments, as follows: $\mathrm{T} 1=\mathrm{CSSV}$ mild strain N1 only, T2 = CSSV mild strain N1 + CSSV severe 1A later, T3 = CSSV mild strain SS365B only, T4 = CSSV mild strain SS365B + CSSV severe $1 \mathrm{~A}$ later, and T5 = healthy (noninoculated) control.

Data collection and analysis. Development of disease symptoms from the time of inoculation to the current stage of the trial after 19 years was followed. Girth measurements at breast height $(1.9 \mathrm{~m}$ from ground level) were recorded every 6 months as an indicator of growth of the cocoa trees inoculated with the mild strain of the virus. Dry cocoa yield (kilograms per hectare) per plot was estimated from the total cocoa pods harvested per treatment per season using the formula [ $(\mathrm{dY}$ $=1,600 / \mathrm{NT}) \times \mathrm{NP} / 28$ ], where $\mathrm{dY}$ is the estimated dry bean yield per hectare, NT is the number of surviving cocoa trees per plot, and NP is number of fresh pods harvested per plot. The constant 28 relates to pod value of 28 pods $/ \mathrm{kg}$ while the number 1,600 represents 1 ha $\left(10,000 \mathrm{~m}^{2}\right)$ divided by the planting distance of 2.5 by $2.5 \mathrm{~m}$. The count data on number of surviving cocoa trees was square root transformed to provide a normalized database to estimate the mortality of the cocoa trees at every stage of the trial. The data set on growth, yield, and survival of the cocoa trees from the mild-strain treatments were then subjected to analysis of variance with GenStat statistical software version 12. Significant differences between two means were compared using Fisher's least significance difference at $P \leq 0.05$.

\section{Results}

Effect of CSSV mild strains on growth of cocoa varieties after superinoculation with severe strains of the virus. Cumulative girth increments and their interactions with the treatments were significant $(P<0.05)$ with regards to the mild-strain inoculations and cocoa varieties. This observation was consistent with all of the cocoa varieties from the initial stages of the trial up to the 15th year after planting. Growth after this period normalized and became insignificant $(P>0.05)$, with minor girth increments for all the treatments. The cocoa trees inoculated with mild strain N1 had significantly $(P<0.05)$ higher stem girth increments than those inoculated with the SS365B mild strain and the healthy (noninoculated) treatments (Table 1), while growth (girth increment) was continuous and normalized after the 15th year (Fig. 1). It was further noted that cocoa varieties T85/799 $\times$ Pa7/808 and T85/799 $\times$ T79/501 had bigger stem girths (better growth) throughout the trial than the most susceptible Amelonado cocoa (Table 1).

Effect of CSSV mild strain on cumulative yield (mean yield of dry cocoa beans in kilograms per hectare) after superinoculation with severe strains of the virus. The effect of mild-strain inoculation and cocoa variety on cumulative yield (kilograms per hectare) was significant $(P<0.05)$ from the outset of the trial until the 20th year after planting. After this period, the yield normalized without any significant differences $(P>0.05)$ for all the treatments (Table 2), while the mild-strain-protected seedlings continued to out-yield the non-mild-strain-protected seedlings after the fifth year (Fig. 2). However, it was noted that trees inoculated with the mild strain alone (SS365B and N1) cumulatively out-yielded the healthy (no mild strain) treatment in the presence of the severe strains either naturally or inoculated. Furthermore, the mild and severe virus strain combinations (i.e., SS365B $+1 \mathrm{~A}$ and N1 + 1A) also out-yielded the healthy (noninoculated) cocoa trees for all the successive years of the

Table 1. Effect of Cocoa swollen shoot virus mild strain inoculations on cumulative mean stem girth of cocoa progenies from 1996 to $2014^{\mathrm{a}}$

\begin{tabular}{|c|c|c|c|c|c|c|}
\hline \multirow[b]{3}{*}{ Variety } & \multicolumn{6}{|c|}{ Stem girth $(\mathbf{c m})$} \\
\hline & \multicolumn{5}{|c|}{ Strain } & \multirow[b]{2}{*}{ Variety mean } \\
\hline & Healthy & N1 & $\mathrm{N1}+\mathbf{1 A}$ & SS365B & SS365B + 1A & \\
\hline Amelonado & 32.54 & 36.01 & 32.41 & 33.51 & 29.68 & 32.83 \\
\hline $\mathrm{T} 79 / 467 \times \mathrm{T} 87 / 1312$ & 36.95 & 38.86 & 29.70 & 38.71 & 36.89 & 36.22 \\
\hline T85/799 × Amelonado & 35.22 & 36.06 & 37.07 & 32.38 & 33.07 & 34.76 \\
\hline $\mathrm{T} 85 / 799 \times \mathrm{Pa} 7 / 808$ & 42.21 & 40.95 & 34.49 & 41.02 & 33.37 & 38.41 \\
\hline $\mathrm{T} 85 / 799 \times \mathrm{T} 65 / 362$ & 36.83 & 36.75 & 31.92 & 35.31 & 31.58 & 34.48 \\
\hline $\mathrm{T} 85 / 799 \times \mathrm{T} 79 / 501$ & 40.12 & 37.45 & 32.91 & 37.34 & 35.91 & 36.75 \\
\hline Strain mean & 37.31 & 37.68 & 33.08 & 36.38 & 33.42 & $\ldots$ \\
\hline
\end{tabular}

${ }^{a}$ Least significance difference at $P \leq 0.05$ : Variety $=2.46$ and Strain $=2.24$. 
trial. The type of cocoa variety grown affected yield significantly $(P<0.05)$. Cocoa variety T85/799 $\times$ Pa7/808 inoculated with mild strains N1 and SS365B was the highest-yielding progeny while Amelonado had the least yield. This observation was consistent for the period of the trial.

Effect of CSSV mild strain on cumulative survival of cocoa trees after superinoculation with severe strains of the virus. Cocoa tree survival was highest in the mild-strain (SS365B and N1)- protected treatments in the presence of the CSSV severe strain than in the noninoculated control and CSSV severe 1A plots (Table 3). Variety $\mathrm{T} 85 / 799 \times \mathrm{Pa} 7 / 808$ inoculated with mild strain $\mathrm{N} 1$ once again had more cocoa trees surviving than the other treatments. The intensity of the severe $1 \mathrm{~A}$ spread may have overwhelmed protective capability of the mild strain (Figs. 3 and 4). It was noted that the severe effects of the $1 \mathrm{~A}$ strains masked the protective capability of the mild strains over time, with Amelonado being severely affected.

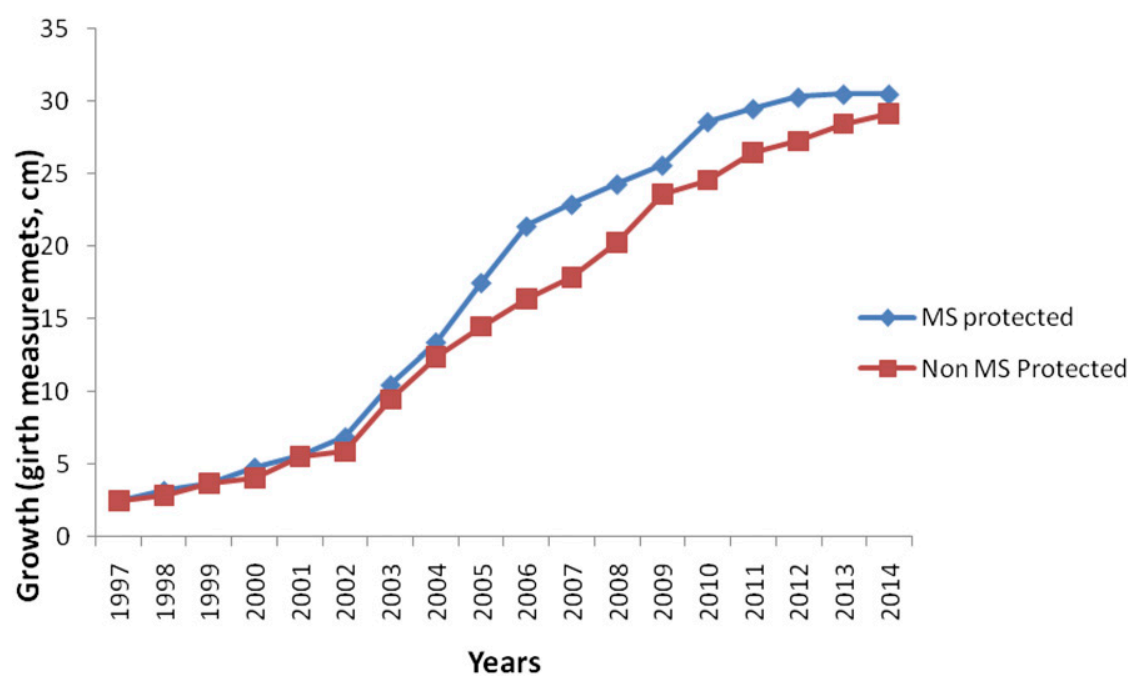

Fig. 1. Growth (girth increments) recorded on the treatments over time.

Table 2. Cumulative yield (dry beans) (1999 to 2015) of Cocoa swollen shoot virus-inoculated cocoa varieties on plot A23 for the year 2014 to $2015^{\text {a }}$

\begin{tabular}{|c|c|c|c|c|c|c|}
\hline \multirow[b]{3}{*}{ Variety } & \multicolumn{6}{|c|}{ Yield (kg/ha) } \\
\hline & \multirow[b]{2}{*}{ Noninoculated } & \multicolumn{4}{|c|}{ Strain } & \multirow[b]{2}{*}{ Variety mean } \\
\hline & & N1 & $\mathrm{N1}+\mathbf{1 A}$ & SS365B & SS365B + 1A & \\
\hline Amelonado & 2,187 & 2,877 & 2,427 & 3,905 & 2,237 & 2,726 \\
\hline $\mathrm{T} 79 / 467 \times \mathrm{T} 87 / 1312$ & 3,514 & 3,782 & 2,909 & 3,764 & 3,513 & 3,496 \\
\hline T85/799 × Amelonado & 3,482 & 3,583 & 3,304 & 3,641 & 3,349 & 3,471 \\
\hline $\mathrm{T} 85 / 799 \times \mathrm{Pa} 7 / 808$ & 3,924 & 5,218 & 3,892 & 5,084 & 3,794 & 4,382 \\
\hline $\mathrm{T} 85 / 799 \times \mathrm{T} 65 / 326$ & 3,593 & 3,587 & 3,218 & 3,528 & 3,387 & 3,463 \\
\hline $\mathrm{T} 85 / 799 \times \mathrm{T} 79 / 501$ & 3,920 & 3,567 & 3,724 & 3,532 & 3,453 & 3,639 \\
\hline Strain mean & 3,436 & 3,769 & 3,245 & 3,909 & 3,288 & $\ldots$ \\
\hline
\end{tabular}

a Least significance difference (5\%): Variety and Strain = not significant.

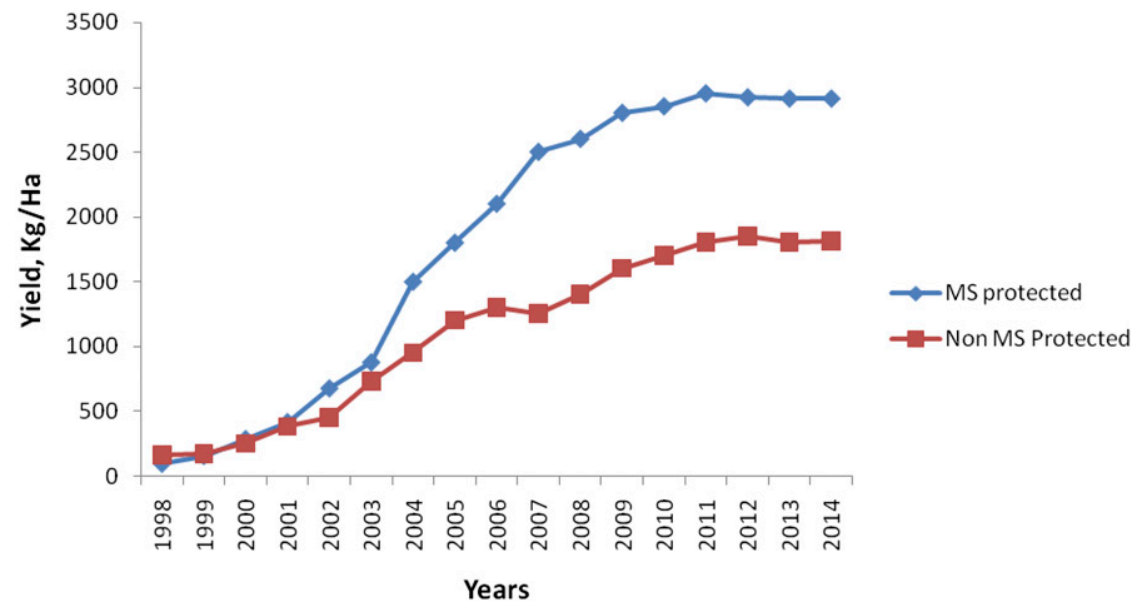

Fig. 2. Yield (kilograms per hectare) of dry cocoa beans recorded on the treatments over time. 
Table 3. Cumulative number of cocoa tree survivals of the mild-strain treatments (1998 to 2014)

\begin{tabular}{lc}
\hline Treatment & Number of cocoa plants \\
\hline Variety & \\
T85/799 $\times$ Pa7/808 & 12 \\
T85/799 $\times$ T65/362 & 9 \\
T85/799 $\times$ T79/501 & 10 \\
T85/799 $\times$ Amelonado & 5 \\
T79/467 $\times$ T85/1312 & 9 \\
Amelonado & 3 \\
LSD $(0.05)^{\text {b }}$ & 2.4 \\
Strain & \\
N1 & 12 \\
N1 +1 A & 6 \\
SS365B & 10 \\
SS365B +1 A & 5 \\
LSD $(0.05)^{\mathbf{b}}$ & 2.7 \\
\hline
\end{tabular}

a Survival of cocoa plants out of initial 20 trees per plot.

b Least significance difference at $P \leq 0.05$.
More deaths of cocoa trees were recorded after this period, translating into drastic reduction in yield from the mild-strain-inoculated cocoa trees.

\section{Discussion}

Application of mild-strain cross-protection techniques to control plant viruses have been known since the late 1920s and 1930s, when it was discovered that attenuated forms (weaker types) of some viruses that normally cause severe infection such as tobacco mosaic tobamovirus (McKinney 1929) and potato Y potyvirus (Salaman 1937) were able to cross-protect against severe (forms) infections of these viruses. It was further discovered that mild isolates of the severe virus strains, when inoculated to susceptible plants, could prevent infection by closely related severe strains (Fulton 1986), albeit the underlying principle was not well understood. Sequeira (1984), Sherwood (2007), and Urban et al. (1990) discussed several possible reasons to explain the concept and underlying mechanism of mild-strain cross protection. However, it is acknowledged that some plant viruses such as Citrus tristeza virus in Brazil (Muller and Costa 1977) and Tomato mosaic virus in the United Kingdom have been effectively managed in the past using the mild-strain cross-protection technique. Furthermore, the mild-strain protection technique has also been used to successfully

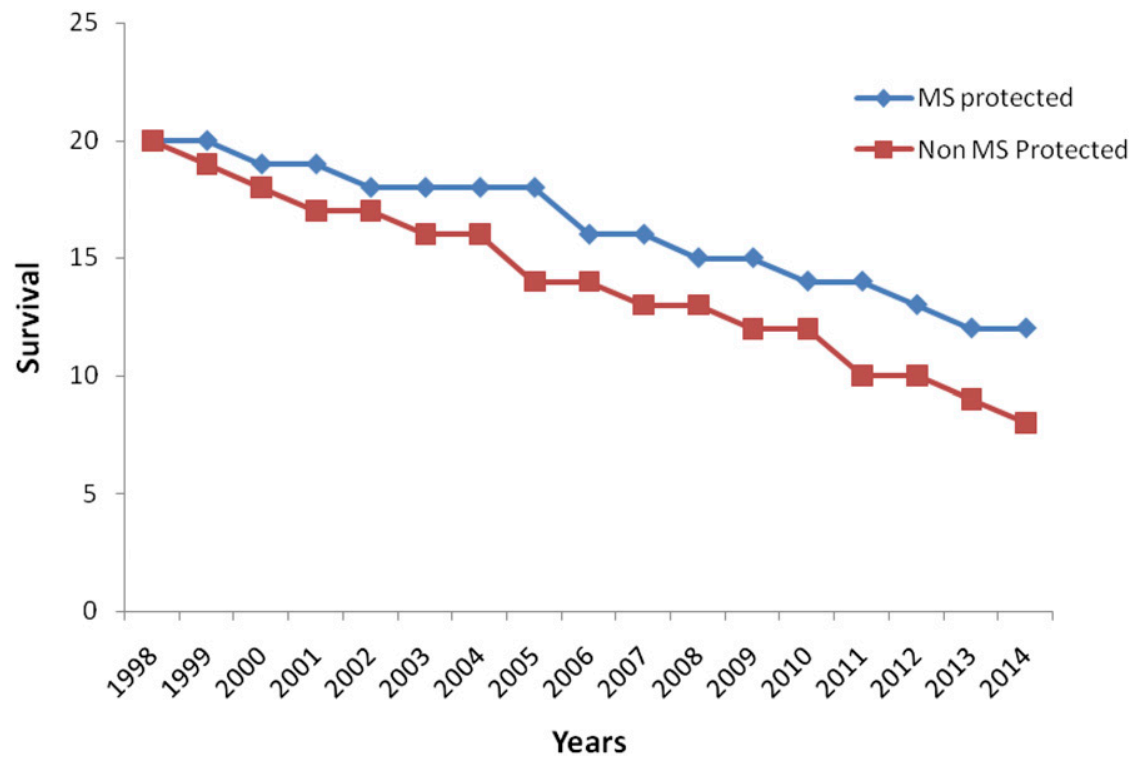

Fig. 3. Number of surviving cocoa trees recorded on the treatments over time.

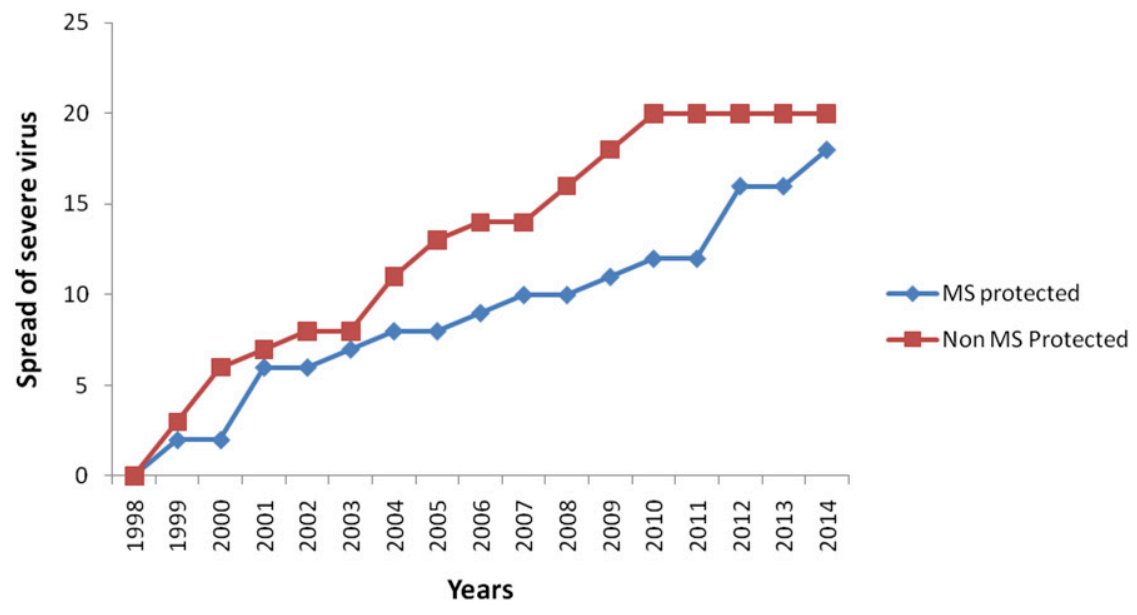

Fig. 4. Spread of severe infections recorded on the treatments over time. 
manage several other plant viruses, including papaya ringspot potyvirus, passion fruit woodiness potyvirus, citrus concave gum, peach and apple mosaic virus, tomato aspermy cucumovirus, avocado sunblotch viroid, and zucchini yellow mosaic (Lecoq et al. 1991).

The earliest evidence on the potential of the mild-strain technology to protect cocoa plants against the damaging effects of virulent strains of the CSSV in Ghana was provided by Crowdy and Posnette (1947) and Posnette and Todd (1951, 1955). Although these early studies showed the possibility that mild strains of the virus could mitigate the effect of the severe strains, there were some reservations regarding its adoption and usage at the time, pending further investigations (Crowdy and Posnette 1947; Hughes and Ollennu 1994; Ollennu and Owusu 1989; Owusu 1996; Posnette and Todd 1955). This was because it was suggested that the mild-strain-protected trees might also harbor virulent strains which might spread to other cocoa trees. It was also believed that the mild strain could mutate and that there might be some synergetic or antagonistic effect when the two strains are together (Crowdy and Posnette 1947; Hughes and Ollennu 1994; Ollennu and Owusu 1989; Owusu 1996; Posnette and Todd 1955). It was again argued that deliberate dissemination of a mild strain was incompatible and inappropriate with the attempts being made at the time to control all outbreaks through elimination of sources of infection, regardless of the virulence of strains involved, through the cutting-out program (Hughes and Ollennu 1994; Ollennu and Owusu 1989; Owusu 1996).

Due to these considerations and reservations, the mild-strain technique was not considered as part of the control program for the disease in Ghana unless further studies were carried out to assess its long-term sustainability and the stability of the mild strains in cocoa (Hughes and Ollennu 1994). These considerations necessitated the need to further investigate the potential of the available mild strains to offer protection; hence, the initiation of several mild-strain field investigations in the early 1990 s to further evaluate the long-term potential of the phenomenon in cocoa (Hughes and Ollennu 1994; Ollennu and Owusu 1989; Posnette and Todd 1955).

Effect of CSSV mild strains on growth of cocoa. The prospect of the two mild strains (N1 and SS365B) in the long term to minimize the effect of the severe strains and sustain growth of cocoa trees was evident from the analysis of the cumulative growth data for the last two decades (Hughes and Ollennu 1994; Ollennu and Owusu 1989; Owusu 1996). It was established that the mild-strain-protected cocoa trees grew better than the healthy (mild-strain-noninoculated cocoa trees) in the presence of the severe strains. This observation was consistent from the outset of the trials, with all of the cocoa varieties from the initial stages of the trial up to the 15 th year after planting, and confirmed the protective effect of the mild strains, as indicated earlier by Posnette and Todd $(1951,1955)$ and Ollennu et al. (1994). Growth after the 10th year normalized and became insignificant, with minor girth increments for all the treatments. The N1 mild-strain-inoculated cocoa trees had significantly $(P<0.05)$ bigger stem girths than trees inoculated with mild strain SS365B and the healthy controls. Cocoa varieties T85/799 $\times$ Pa7/808 and T85/799 $\times$ T79/501 had better growth throughout the trial than the most susceptible Amelonado cocoa used in the trial. An explanation for the apparent boost of growth of the cocoa trees with respect to the mild strain $\mathrm{N} 1$ inoculations needs to be ascertained from further investigations.

Effect of CSSV mild strains on yield of cocoa. The influence of the mild strains to mitigate the effect of the severe strains to protect cocoa trees to sustain yield was also shown from the cumulative analysis of yield of the cocoa varieties over the last two decades and confirms earlier results by Ollennu et al. (1994). The effect of the mild-strain inoculations on the cocoa varieties on cumulative yield (kilograms per hectare) was significant from the outset of the trial. However, after a period, the yield normalized without any significant differences at the10th year after planting. It was observed that trees inoculated with the mild strain alone (SS365B and N1) cumulatively outyielded the healthy (mild-strain-noninoculated) plants. Furthermore, the mild and severe virus strain combinations (i.e., SS365B $+1 \mathrm{~A}$ and $\mathrm{N} 1+1 \mathrm{~A}$ ) also out-yielded the healthy (uninoculated) cocoa trees for all the successive years of the trial. The type of cocoa variety grown affected yield significantly $(P<0.05)$. T85/799 $\times$ Pa7/808 cocoa inoculated with mild strains N1 and SS365B was the highest yielding progeny while Amelonado had the least yield. This observation was consistent for the period of the trial.

Effect of CSSV mild strains on survival of cocoa. The longevity of the cocoa trees was prolonged with the mild-strain inoculations over the period of the trials. The mild-strain (SS365B and N)-protected treatments resulted in lower numbers of deaths of cocoa trees in the presence of the CSSV severe strain of the virus than the healthy controls and the severely infected cocoa trees without mild-strain protection. T85/799 $\times$ Pa7/808 cocoa inoculated with mild strain N1 once again had more cocoa tree survivals than the other treatments.

\section{Conclusions}

Mild strains N1 and SS365B maintained the growth and yield of different cocoa progenies, caused low expression of CSSV severe strain $1 \mathrm{~A}$ for a period of time, and was significant compared with noninoculated cocoa trees. However, this immunity conferred by the mild strains broke down over time in the presence of the severe strains. It was noted that, by the fifteenth year, growth and yield of the mild-strain-protected plants declined significantly, with an increased spread of the severe strain and the death of more cocoa trees. This observation confirms earlier reports by Ollennu and Owusu (1989) that showed that the immunity offered by the mild strains might not be permanent. They also submitted that the inherent immunity offered by tolerant cocoa hybrids eventually breaks down, mostly after 20 years.

Therefore, it was concluded that the long-term cross-protection offered by N1 and SS365B mild strains led to sustained growth, low expression of CSSV severe strain 1A, and high yield for the testing progenies during the early years of the trial. However, it was noted that the immunity conferred by the mild strains broke down with an increased spread of the severe strains over time. It is now noted that the severe effects of the $1 \mathrm{~A}$ strains masked the protective capability of the mild strains on growth and yield with, Amelonado cocoa being severely affected for the duration of the trial. Therefore, Amelonado is further confirmed to be very susceptible to both the mild and severe strains of CSSV compared with the Upper Amazon cocoa hybrids with or without mild-strain protection.

\section{Acknowledgments}

We thank fellow scientists for their useful comments and suggestions on the draft manuscript; and all of the technical staff of the Virology Section of the Plant Pathology Division of CRIG, most especially the late G. K. Johnson, as well as H. Oboom, B. Quarshie, B. Asiedu, and A. Opare, for their continuous efforts to maintain the field plots and also routinely collect data from the various treatments.

\section{Literature Cited}

Ackonnor, J. B. 1997. Preliminary studies on breeding and predation on Scymnus (Pullus) sp. and Hyperaspis egregia Mader on Planococcoides njalensis (Laing). Pages 238-241 in: Proc. First Int. Cocoa Pests Dis. Semin. L. A. A. Ollennu, G. K. Owusu, and B. Padi, eds. Accra, Ghana.

Ameyaw, G. A., Dzahini-Obiatey, H. K., and Domfeh, O. 2014. Perspectives on cocoa swollen shoot virus disease (CSSVD) management in Ghana. Crop Prot. 65:64-70.

Crowdy, S. H., and Posnette, A. F. 1947. Virus diseases of cacao in West Africa II Cross-immunity experiments with viruses 1A, 1B, and 1C. Ann. Appl. Biol. 34: 403-411.

Domfeh, O., Dzahini-Obiatey, H., Ameyaw, G. A., Abaka-Ewusie, K., and Opoku, G. 2011. Cocoa swollen shoot disease situation in Ghana: A review of curren trends. Afr. J. Agric. Res. 6:5033-5039.

Dzahini-Obiatey, H., Domfeh, O., and Amoah, F. M. 2010. Over seventy years of a viral disease of cocoa in Ghana: From researchers' perspective. Afr. J. Agric. Res. 5:476-485.

Fulton, R. W. 1986. Practices and precautions in the use of cross protection for plant virus control. Annu. Rev. Phytopathol. 24:67-81.

Hanna, A. D. 1954. Research in the use of systemic insecticides to control the mealybug vectors of swollen shoot disease of cocoa. Phytiat-Phytophram Special Issue: 426-432.

Hanna, A. D., Judenko, E. B., and Heatherington, W. 1955. Systemic insecticides for the control of insects transmitting the swollen shoot virus of cocoa in the Gold Coast. Bull. Entomol. Res. 46:669-710.

Hughes, J. d'A., and Ollennu, L. A. A. 1994. Mild strain protection of cocoa in Ghana against cocoa swollen shoot virus-A review. Plant Pathol. 43:442-457. 
Lecoq, H., Lemair, J. M., and Wipf-Scheibel, C. 1991. Control of zucchini yellow mosaic virus in squash by cross protection. Plant Dis. 75:208-211.

McKinney, H. H. 1929. Mosaic diseases in the Canary Islands, West Africa, and Gibraltar. J. Agric. Res. 39:557-578.

Muller, E. 2008. Cacao swollen shoot virus. Chapter 24 in: Characterization, Diagnosis and Management of Plant Viruses: Industrial Crops. G. P. Rao, S. M. Paul Khurana, and S. L. Lenardon, eds. Studium Press, Houston, TX.

Muller, G. W., and Costa, A. S. 1977. Further evidence on protective interference in citrus tristeza. Pages 71-82 in: Proc. 4th Conf. Int. Organ. Citrus Virol.

Ollennu, L. A. A., and Owusu, G. K. 1989. Isolation and study of mild strains of cocoa swollen shoot virus for possible cross protection. Pages 199-222 in: Proc. 4th Int. Plant Virus Epidemiol. Workshop, Montpellier, France.

Ollennu, L. A. A., Owusu, G. K., and Oboom, H. 1994. Mild strain protection of young cocoa plants. Pages 117-118 in: Annual Report, 1993/94. Cocoa Research Institute, New Akim Tafo, Ghana.

Owusu, G. K. 1996. Mild strain protection of young cocoa plants. Pages 113-116 in: Annual Report, 1995/96. Cocoa Research Institute, New Akim Tafo, Ghana.

Posnette, A. F. 1940. Transmission of "swollen shoot" disease of cacao. Trop. Agric. Trinidad 17:98.

Posnette, A. F. 1941. Swollen shoot virus disease. Trop. Agric. Trinidad 18:87-90.

Posnette, A. F., Robertson, N. F., and Todd, J. McA. 1950. Virus diseases of cocoa in West Africa V: Alternative host plants. Ann. Appl. Biol. 37:229-240.

Posnette, A. F., and Strickland, A. H. 1948. Virus diseases of cocoa in West Africa: Technique of insect transmission. Ann. Appl. Biol. 35:53-63.
Posnette, A. F., and Todd, J. McA. 1951. Virus diseases of cocoa in West Africa. VIII. The search for virus resistant cacao. Ann. Appl. Biol. 38:785-800.

Posnette, A. F., and Todd, J. McA. 1955. Virus diseases of cocoa in West Africa IX. Strain variation and interference in virus 1A. Ann. Appl. Biol. 43:433-453.

Roivainen, O. 1976. Transmission of cocoa viruses by mealybugs (Homoptera: Pseudococcidae). J. Sci. Agric. Soc. Finl. 48:433-453.

Salaman, R. N. 1937. Acquired immunity against the 'Y' potato virus. Nature 139: 924-925.

Sequeira, L. 1984. Cross protection and induced resistance: Their potential for plant disease control. Trends Biotechnol. 2:25-29.

Sherwood, J. L. 2007. Mechanism of cross-protection between plant virus strains Pages 136-150 in: Ciba Foundation Symposium 133-Plant Resistance to Viruses. D. Evered and S. Harnett, eds. John Wiley \& Sons, Ltd., Chichester, UK.

Stevens, W. F. 1936. Swollen shoot and die-back e a new disease of cocoa. Gold Coast Cocoa Farmer 5:7-8.

Thresh, J. M., Owusu, G. K., Boamah, A., and Lockwood, G. 1988. Cocoa swollen shoot: An archetypal crowd disease. Z. Pflanzenkrankh. Pflanzenschutz 95: 428-446.

Urban, L. A., Sherwood, J. L., Rezende, J. A. M., and Melcher, U. 1990 Examination of mechanisms of cross protection with non-transgenic plants. Pages 415-426 in: Recognition and Response in Plant-Virus Interactions. NATO ASI Series, Vol. 41. R. S. S. Frazer, ed. Springer, Berlin, Heidelberg. 